\title{
Urdu in Devanagari: Shifting orthographic practices and Muslim identity in Delhi
}

\author{
R I Z W A N A H M A D \\ Qatar University P.O. Box 2713, Doha, Qatar \\ rizwan.ahmad@qu.edu.qa
}

A B S T R A C T

In sociolinguistics, Urdu and Hindi are considered to be textbook examples of digraphia - a linguistic situation in which varieties of the same language are written in different scripts. Urdu has traditionally been written in the Arabic script, whereas Hindi is written in Devanagari. Analyzing the recent orthographic practice of writing Urdu in Devanagari, this article challenges the traditional ideology that the choice of script is crucial in differentiating Urdu and Hindi. Based on written data, interviews, and ethnographic observations, I show that Muslims no longer view the Arabic script as a necessary element of Urdu, nor do they see Devanagari as completely antithetical to their identity. I demonstrate that using the strategies of phonetic and orthographic transliteration, Muslims are making Urdu-in-Devanagari different from Hindi, although the difference is much more subtle. My data further shows that the very structure of a writing system is in part socially constituted. (Script-change, Urdu, Urdu-in-Devanagari, Hindi, Arabic script, Devanagari, orthography, transliteration)*

\section{N T R O D U C T I O N}

In the sociolinguistics literature, Urdu and Hindi are considered to be quintessential examples of digraphia - a linguistic situation in which varieties of the same language are written using different writing systems. In ordinary conversational registers, Urdu and Hindi are largely mutually intelligible. Therefore, it is the choice of script that plays a crucial role in making them distinct. Urdu has traditionally been written in the Arabic script, whereas Hindi is written in Devanagari. Socially, the digraphic situation is related to the religious identities of Muslims and Hindus and their social desire for linguistic differentiation. Scholars argue that the Arabic script, because of its association with the Holy Quran, symbolizes Muslim identity, whereas Devanagari, because of its relationship with Hindu scriptures written in Sanskrit, represents Hindu identity (e.g. Kelkar 1968; Dale 1980; C. R. King 1994; R. D. King 2001).

Analyzing the recent orthographic practices of writing Urdu in Devanagari (henceforth also Ur-Nag), this article challenges the traditional ideology that the choice 
of script is crucial in differentiating Urdu and Hindi. Drawing on published written data, interviews, surveys, and ethnographic observations, I show that Muslims in India no longer view the Arabic script as a necessary, let alone defining, element of Urdu, nor do they believe that Devanagari is completely antithetical to Urdu and their Muslim identity. By analyzing Ur-Nag texts, I show that while some features of Urdu are being lost, many are being preserved. Using the strategies of phonetic and orthographic transliteration (Androutsopoulos 2009), Muslims are making Urdu-in-Devanagari different from Hindi, although the difference is much more subtle and nuanced. Theoretically, this study suggests that the social symbolic meanings of writing systems do not stem from the writing systems themselves but are produced and maintained through the orthographic practices in which users of the writing systems engage.

This article further suggests that the structure of a writing system - its graphemes and the rules that govern how they combine with each other, that is, its graphotacticsare not a mere technical matter of representing sounds on paper. I argue that the structure of a writing system is in part constituted by social and cultural factors that involve issues of identity. I show that Muslims are modifying the structure of Devanagari by introducing a diacritic called a bindi to represent the distinctive Urdu phonemes. They are also trying to preserve purely orthographic features of Urdu in Devanagari, for example, the "silent" consonant letter ain, $<_{\varepsilon}>$, which is actually phonemically empty. ${ }^{1}$ They use the schwa-grapheme $<अ>$ to represent ain. In standard Devanagari, schwa is never written after a consonant because it is assumed to be part of it, for example, the grapheme $<$ क $>$ represents the two phonemes /k/ and /ə/. In Ur-Nag texts, however, this rule is flouted in order to ensure that the silent Urdu letter ain is represented.

This radical change in the orthographic practices of Muslims is reflective and simultaneously constitutive of a constellation of changes in the social, political, and educational contexts. First, Urdu in postcolonial discourse became associated with Pakistan and Muslim separatism. ${ }^{2}$ Second, in Old Delhi, Urdu also became stigmatized as the language of the poor, uneducated, and ghettoized Muslim community. Third, although Urdu is recognized in the Constitution of India as one of the twenty-two scheduled languages, due to the distorted implementation of the language policy, opportunities to learn Urdu in government schools in North India are almost nonexistent (Sachar 2006). Finally, literacy practices involving Devanagari are viewed as patriotic and nationalistic since it is associated with Hindi.

In this article I first give a short sociolinguistic background on Urdu and Hindi, followed by a discussion of the theoretical framework and data. Next, I discuss the social context of the changing literacy practices among Muslims. Then I examine Ur-Nag texts and discuss the features that are being lost and those that are being preserved. I also discuss the transformation in the ideologies that link the Arabic script and Urdu. Finally, I summarize the results of my study in the last section. 


\section{Background on Urdu and Hindi}

Urdu and Hindi belong to the Indo-Aryan subbranch of the Indo-European language family. On the spoken level, the relationship between them is comparable to that between two varieties of English. In ordinary conversational registers, Urdu and Hindi speakers understand each other pretty well. ${ }^{3}$ This is because Urdu and Hindi are marked by what Woolard (1998a) calls bivalency - the use of linguistic elements that could simultaneously belong to more than one language. Bivalency between Urdu and Hindi permeates all levels of the linguistic systems - phonological, morphological, lexical, and syntactic.

Urdu and Hindi, however, are written in different scripts. Urdu employs a modified version of the Arabic script. The modification involved creating graphemes for Indic phonemes such as breathy stops, for which the Arabic script did not have symbols. A consequence of adopting the Arabic script is that in the Urdu alphabet, for one and the same phoneme, there is more than one grapheme. For example, the phoneme /s/ is represented by three graphemes $\langle\mathrm{w}\rangle,\langle\dot{ث}\rangle$, and $\langle\boldsymbol{\nu}\rangle$. The graphemes $\langle\dot{ث}\rangle$ and $\langle\boldsymbol{\rho}\rangle$, which in Arabic stand for the phonemes $/ \theta /$ and pharyngealized $/ \mathrm{s} /$, are phonemically empty in Urdu. Other phonemically empty graphemes in the Urdu alphabet are: $\left\langle_{\tau}\right\rangle,\left\langle_{j}\right\rangle,\left\langle_{j}\right\rangle$, $\langle\boldsymbol{b}\rangle,\langle\boldsymbol{b}\rangle$, and $\left.<_{\varepsilon}\right\rangle$. Urdu has also borrowed the phonemes /f/, /z/, /x/, /b/, and $/ \mathrm{q} /$ from Arabic and Persian and has preserved them. These phonemes are quite crucial in differentiating Urdu from Hindi. ${ }^{4}$

Hindi, by contrast, is written in the Devanagari script - the script used to write Sanskrit, the sacred language of Hindus. ${ }^{5}$ Another point of distinction is that although Hindi has also borrowed words from Persian and Arabic - much less than Urdu, however - the above phonemes have been NATIVIZED in Hindi. So, for example, the word for 'pen', a loanword from Arabic, is pronounced as /qələm/ in Urdu but $/ \mathrm{k} ə \mathrm{l} ə \mathrm{~m} /$ in Hindi. The borrowed phoneme /q/ has been preserved in Urdu but nativized as $/ \mathrm{k} /$ in Hindi.

Politically, script has been a contentious factor. Muslims and Hindus have fought battles for the official recognition of their respective languages and scripts (C. R. King 1989, 1992, 1994; Ahmad 2008a). The struggle for Hindi has been extensively studied as part of the Hindu nationalism (van der Veer 1994; Dalmia 1997; Zavos 2000; Orsini 2002). I, however, argue that these studies do not go beyond the nineteenth-century contexts and cannot account for the transformations in the orthographic practices of Muslims. Moreover, a study of Urdu-in-Devanagari sheds light on how speakers construct and respond to postcolonial realities.

TH E O R E T I C A L F R A M E W O R K

Making a departure from traditional approaches to the study of literacy as a socially neutral, technological skill, recent studies locate literacy practices in a sociocultural context informed by relations of power and ideology (e.g. Street 1995). Drawing 
upon this approach, recent sociolinguistic research treats orthographic choices as sociocultural practices and a means of social positioning. (e.g. B. Brown 1993; Schieffelin \& Charlier Doucet 1994; Balhorn 1998; Sebba 1998a, 2006, 2007; Androutsopoulos 2000, 2009; Jaffe \& Walton 2000). In this body of literature, writing systems and orthography are treated as ways of constituting and representing (and often contesting) different identities.

Balhorn (1998), for example, argues that nonstandard spellings used to represent African-American English in literature derive their meaning from their opposition to the standard orthography. Similarly, Sebba (1998a) shows that Creole writers choose spelling conventions that show difference and distance from British English, even in words that are not pronounced very differently in Creole, for example, yuh 'you', duh 'do', and tuff 'tough'. Another good example of how orthography is employed for identity work is the use of $\langle\mathrm{k}\rangle$ for the standard $<\mathrm{c}>$, or $\langle\mathrm{qu}>$ in the Spanish subculture as a means of symbolic opposition and resistance to the mainstream culture (Sebba 2007).

\section{Data}

This article is based on an analysis of a variety of data sources. While writtenlanguage data constitutes the bulk of the study, I also include interviews, surveys, and ethnographic observations. The written data come from two sourcesMahakta Anchal (henceforth Anchal), and Muntakhab Ahadis (henceforth Ahadis). ${ }^{6}$ Anchal, launched in 1993 in Delhi, is a general-interest, popular, family magazine. In its format, it is modeled on the magazine Pakiza Anchal, published in the Arabic script, which has been in print for a much longer time. The two magazines do not publish the same set of articles in the Arabic and the Devanagari versions. However, both are published by the same publishing house and some authors write for both, which suggests that they may recycle some of their material in different issues of the magazines.

The editorial of the magazine starts with a translation (and transliteration into Devanagari) of the Islamic phrase "In the name of Allah, the most Benevolent, the most Merciful!" This line functions as a framing device for the magazine; it makes it clear that the contents of the magazine are targeted to a Muslim audience. All writers of the articles are Muslim, except occasional contributions by Hindu readers. ${ }^{7}$ Most issues of Anchal contain fiction, especially short stories and novelettes. They also contain Urdu poetry, articles on health and beauty, matrimonial advertisements, and quotations, and stories from the Quran and Hadith. ${ }^{8}$ Some issues of the magazine also carry a column called zaban $(U r d u) s v d^{h}$ are 'Improve your (Urdu) language'. The name of the column suggests that the producers of the magazine believe that the text of the magazine is Urdu despite the fact that it is written in Devanagari. I return to this issue later.

Ahadis is a religious book containing narrations of Prophet Mohammad, published originally in the Arabic script, which has recently been transliterated into 
Devanagari. ${ }^{9}$ The transliterated version is extremely popular among the younger generation of Muslims. During my fieldwork, I discovered that many bookstores in Old Delhi carry both Arabic and Devanagari versions. I also noticed that many mosques in Old Delhi have copies of the book in both scripts.

In addition to these sources, I also analyze some data from online Hindi newspapers to show the contrast in the representation of the distinctive Urdu phonemes. The textual and quantitative data is supplemented with observations and insights gained from an ethnographic study that I conducted in 2005 and 2006. I also include some interviews with participants who produce and use Urdu-in-Devanagari texts. Also included is a survey examining the attitudes of speakers and writers of Hindi regarding the spelling innovations introduced by Muslims in the structure of Devanagari.

\section{S O C I O L I N G I S T I T R A N F O R M T I O N O F O L D D E L H I}

Four major factors are relevant to understanding the transformation of the orthographic practices of Muslims. First, after the Partition of India and the creation of the Muslim state of Pakistan in 1947, Urdu became stigmatized in India as the language of Muslim separatism. Urdu, before the Partition, was not categorically indexical of any ethnic identities; it indexed a broader urban, educated, middle class identity. Second, in Old Delhi, because of the mass migration of middleclass Muslims to Pakistan, Urdu began to be seen as the language of poor, uneducated, ghettoized Muslims. Third, Urdu is not available in most government schools, which makes it difficult for Muslim students who might be interested to learn it. Finally, since Devanagari is the official script for writing Hindi, literacy involving Devanagari is often viewed as patriotic.

The Partition brought about two important changes related to the symbolic meanings of Urdu. First, on the national level, in the postcolonial discourse, Hindus began to see Urdu as the language of Muslims and often as the language of separatism associated with Pakistan. Purushottam Das Tandon, a leader of the Congress party remarked in 1948:

The Muslims must stop talking about a culture and civilization foreign to our culture and genius. They should accept Indian culture. One culture and one language will pave the way for real unity. URDU SYMBOLIZES A FOREIGN CULTURE. Hindi alone can be the unifying factor for all the diverse forces in the country. (Khalidi 1995:138, emphasis mine)

Here one can see the establishment of the iconization of Urdu with lack of patriotism and foreignness and Hindi as the language of nation-building. Metcalf (2006:66) notes the consequences of the Partition for Urdu in India: "In any case, the fact that Urdu then became the national language of Pakistan, a country 
established on the grounds of the religion of the population, made the position of Urdu in its own homeland even more difficult."

The local impact of the Partition on Old Delhi was that, because of the mass migration of the middle-class Muslims, the city was reduced to a ghetto community of poor and uneducated Muslims. According to Pandey (2001:124), by the end of October 1947 about 350,000 Muslims, which was 70\% of the total Muslim population, had left Delhi. As a result, the proportion of Muslims to the total population of Delhi dropped from 32\% in 1931 to 6\% in 1951 (Bakhshi \& Sharma 1995:121). Scholars believe that a majority of Muslims who migrated to Pakistan belonged to the middle class. Singh (2006:39) notes, "Partition depleted the Muslim community of a major segment of the middle classes, elite, professionals, and enterprising population, and left the community impoverished in economic and social terms."

Consequently, in the postcolonial imaginary of Hindus, Muslims of Old Delhi stood for poverty, backwardness, and lack of education. Many Muslim research participants shared with me the embarrassment they often felt telling outsiders that they were from Old Delhi. They told me that they would often lie to outsiders about their residence. These factors combined to create a condition where young Muslims feel ashamed of their identity and its linguistic expression through Urdu. Since the Muslim youth does not have a command of the Urdu alphabet, Urdu-in-Devanagari texts are created FOR them By the older generation Muslims, who know both the Arabic and Devanagari scripts. The Ur-Nag texts therefore cannot be described as subcultural youth vernacular.

\section{The Arabic script: The crumbling shibboleth}

The Arabic script was the most critical element in differentiating Urdu from Hindi. Although some scattered attempts were made in the past to write Urdu in the Roman script, it has mostly been written in the Arabic script. The use of the Roman script was championed by British missionaries and colonial officers. In the first half of the nineteenth century, some missionaries translated the Bible into "Roman Urdu". According to G. Brown (1854), editions of the Bible were printed in Roman Urdu in the nineteenth century. Later, British civil servants encouraged its use, and some pedagogical books were written using the Roman script. ${ }^{10}$ Urdu speakers themselves, however, have not used the Roman script because of the social values attached to the Arabic and Roman scripts. Note also that during the entire Muslim rule, the official language of India was Persian written in the Arabic script. So, literacy in the Arabic script was socially quite valued.

After the Independence of India in 1947, Hindi written in Devanagari became an official language. Since Urdu and Hindi are quite similar languages, Devanagari has been presented as an alternative to the existing Arabic script. Suggestions have come from both within the Muslim community and from without. Rahi Masum Raza, a noted Urdu novelist, argued in an interview in 1990 that unless the Urdu classics were converted into Devanagari, they would become inaccessible 
to the future generation. He also suggested that Urdu speakers should adopt Devanagari for writing Urdu (Russell 1999). ${ }^{11}$

However, Muslims have resisted Devanagari not because of the pragmatic difficulties that the switch might involve, but because they believe that this would mean suspending the distinctions between Urdu and Hindi (Dalvi 1971; Khan 1997; Moghni 1998; Sahar 2001). Dalvi argues:

These days, proposals are being made to change the script of Urdu, because it is being described as a non-scientific script. ... Although Turkish, Indonesian and Malay have abandoned their scripts..., the same will be detrimental to Urdu. The languages that have changed scripts are isolated languages of the region, and therefore they do not risk being merged into other languages. The ecology of Urdu is completely different from those languages. IF THE SCRIPT OF URDU WERE TO CHANGE, URDU WOULD NOT ONLY LOSE ITS DISTINCT IDENTITY BY MERGING INTO HINDI, BUT THE WHOLE LITERATURE SPANNING SEVERAL CENTURIES WOULD GO TO WASTE. $(1971: 364 \text {, emphasis mine) })^{12}$

A more recent voice of opposition to the proposal comes from Faruqi (2006). According to him, the boundary between Urdu and Hindi cannot be maintained without the Arabic script.

The situation today is that, in practical terms, IT IS ONLY THE SCRIPT THAT SEPARATES URDU FROM HINDI... IF URDU ADOPTS THE NAGARI SCRIPT, IT WOULD IMMEDIATELY LOSE ITS IDENTITY. HINDI WOULD SOON ABSORB URDU INTO ITSELF... The magnificent literary treasure of Urdu will have been reduced, through the conversion of these glorious classical treasures, into Hindi literature within no time.... Soon, this treasure will be beyond the reach of those Urdu people who are not familiar with the Nagari script. (Faruqi 2006:137-38, emphasis mine)

During my fieldwork, I met with a retired professor of Urdu who lives behind the Grand Mosque in Old Delhi. While discussing the issue of Urdu in general and the script in particular, he told me how furious he was during the annual Hajj pilgrimage in Mecca when he saw a fellow Muslim pilgrim holding a book of supplication written in Devanagari. He told me that he felt like saying 'allah ki lanət ho tum pər' 'May the curse of God fall upon you!'. For this Urdu speaker, it was almost blasphemous for a Muslim to read Urdu in Devanagari.

Since the issue of script has been quite crucial for Urdu speakers, it was discussed at the fourth International Urdu Conference held in London in June 2006. The panel that discussed the issue of script unanimously agreed that the adoption of a new script would be detrimental to Urdu (Senrai 2006). This shows that there exists a wide rift between the ideologies and practices of the older generation Urdu-speaking elite and the younger generation of ordinary Muslims. Despite such a strong opposition from scholars, writers, and poets, many Urdu speakers have already started to use Devanagari. 
The adoption of Devanagari for Urdu has the potential to obliterate the distinctions between Urdu and Hindi. On the surface level, while Urdu-in-Devanagari looks completely different from Urdu in the Arabic script, it looks quite similar to Hindi. In this section, I discuss the strategies that Muslims are adopting to make Urdu-in-Devanagari different from Hindi. However, a terminological clarification is in order. Ur-Nag texts are not TRANSLATION from Urdu into Hindi but rather TRANSLITERATION (Androutsopoulos 2009) from the Arabic into Devanagari script. ${ }^{13}$ Below is a paragraph in Urdu in the Arabic script and in a Devanagari script, followed by a transliteration and English translation in (1).

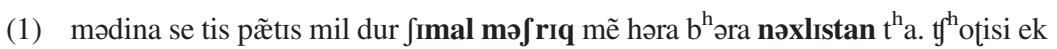
$c^{\mathrm{h}_{\mathrm{i}}} \mathrm{il}, \mathrm{c}^{\mathrm{h}}$ il ke kınare $\mathrm{k}^{\mathrm{h}}$ aḑur ke perõ kā $\phi^{\mathrm{h}}$ und aur səhrai paude ləq-o-dəq təpte huwe is səhra mẽ gəonnat ka səmã paida kıye huwe $\mathrm{t}^{\mathrm{h}} \mathrm{e}$. ye nəxlistan is regzar mẽ yũ ləgta $\mathrm{t}^{\mathrm{h}} \mathrm{a}$ đ̧æse dəhəkte huwe əngarõ mẽ ek $\mathrm{p}^{\mathrm{h}} \mathrm{ul} \mathrm{k}^{\mathrm{h}} \mathrm{rla}$ huwa ho. (Altamash 2005:3)

'About thirty to thirty-five miles North East of Madinah, there was a fertile oasis. A small pond, a group of date palm trees on the banks of the pond, and other desert plants had created a semblance of the Heaven in the scorching desert. This oasis in the desert looked like a flower that had blossomed in a sea of flames.'

The above extract is from the novel hejaz kiãd ${ }^{h} i$ 'The storm of Hejaz' by Enayatullah Altamash. It is clear from the example that the Devanagari version is not a translation from Urdu into Hindi. No words or phrases of the original Urdu have been translated; in a typical translation, Urdu words (shown in bold above) such as fimāl 'north', məfriq 'east', nəxlistan 'oasis', səhrai 'desert-like', and regzar 'desert' will be replaced with their Hindi equivalents. In some Ur-Nag texts, however, some minor changes are often made, which involve replacing obscure and archaic words with common Urdu words.

\section{Lost in transliteration}

An analysis of the Ur-Nag texts shows that there are two processes of transliteration at work - phonetic and orthographic (Androutsopoulos 2009). While the phonetic transliteration allows Muslims to represent in Devanagari the phonemes that make Urdu distinct from Hindi (see the next section), it also results in the loss of historical Urdu spellings containing the phonemically empty graphemes $\langle\dot{ث}\rangle,\left\langle_{\tau}\right\rangle$, $\langle\dot{i}\rangle,\langle\rho\rangle,\langle\dot{\varphi}\rangle,\langle\boldsymbol{b}\rangle,\langle\dot{b}\rangle$, and $\left\langle_{\varepsilon}\right\rangle$ (see BACKGROUND ON URDU AND HiNDI). ${ }^{14}$ Many advocates of script reform including Khan (1971), who calls these graphemes "dead corpses," have argued in the past that in order to make the Urdu alphabet more "scientific," they should be discarded from the Urdu 
alphabet. These suggestions, however, have never been implemented. The Urdu Script Reform Committee, which was constituted in 1973 to look into the Urdu orthography noted:

The different letters that correspond to the same phoneme [phonemically empty graphemes] have become part of our LINGUISTIC INHERITANCE. It is by virtue of these [graphemes] that we have received thousands of valuable words, which are an integral component of our language. (Narang 1974:26, emphasis mine)

The Committee's view clearly indicates that although these graphemes may be phonemically empty to script reformers, they are pregnant with meanings to Urdu speakers. The Committee values these graphemes as part of the linguistic inheritance and thus worthy of maintenance. This again provides a good example of the need for an ideological model of orthography, which goes beyond the technical aspects of writing systems and incorporates the social and cultural practices within which they are embedded.

However, this "linguistic inheritance" is not preserved in Urdu-in-Devanagari (see The REPRESENTATION OF THE URDU GRAPHEMES for two notable exceptions $<_{\tau}>$ and $<_{\varepsilon}>$ ). In both Anchal and Ahadis, for example, all three graphemes of standard Urdu orthography $<$, ص , $>$ that stand for the phoneme /s/ are represented by one single Devanagari grapheme $<$ स $>$. The same holds true of the graphemes $\langle\dot{j}, \dot{j}, \boldsymbol{b}, j>$, which stand for the phoneme $| z /$. The result is that the orthographic difference in standard Urdu orthography between the words

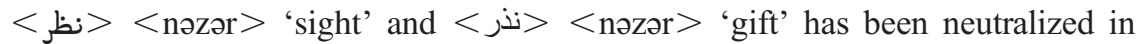
Devanagari as $<$ नज़र $>$. ${ }^{15}$

Table 1 gives examples that show the loss of these graphemes in Urdu-in-Devanagari. A possible reason for the nonrepresentation of these graphemes could be that the writers may not have access to the original Arabic orthography if they do not know the Arabic script already. I return to this in a later section and explain some of the variation in Urdu-in-Devanagari. The principle of phonetic transliteration is more robustly visible in the representation of the distinctive Urdu phonemes, which contributes to making Urdu-in-Devanagari distinct from Hindi.

\section{Representation of the distinctive Urdu phonemes}

As discussed above, in addition to script, Urdu is distinguished from Hindi by the phonemes /f/, /z/, /x/, /s/, and /q/ borrowed from Arabic. These phonemes are seen as the defining features of Urdu on the spoken level. Khan (1997:245) underscores the significance of these phonemes by noting that "on the spoken level, Urdu can be identified by the following borrowed phonemes from Arabic and Persian: qaf, fe, ze, $3 e, x e$, and sain." Khan here refers to the phonemes by the names of their letters, $q a f, f e$, and so on, in the Urdu alphabet.

These phonemes are socially quite salient. Knowledge of Urdu is often measured in terms of their correct pronunciation. If someone does not pronounce 
TABLE 1. Nonrepresentation of Urdu graphemes in Devanagari. [colcnt $=7$ ]

\begin{tabular}{|c|c|c|c|c|c|c|}
\hline Phoneme & $\begin{array}{c}\text { Urdu } \\
\text { grapheme }\end{array}$ & $\begin{array}{l}\text { Devanagari } \\
\text { grapheme }\end{array}$ & $\begin{array}{c}\text { Urdu } \\
\text { example }\end{array}$ & $\begin{array}{l}\text { Ur-Nag } \\
\text { example }\end{array}$ & IPA & Gloss \\
\hline /s/ & $\begin{array}{l}<\dot{ }> \\
<m> \\
<ص\end{array}$ & $<\mathrm{H}>$ & $\begin{array}{l}>> \\
>> \\
>>\end{array}$ & $\begin{array}{l}<\text { तासीर }> \\
<\text { रसूल }> \\
<\text { मनसब }>\end{array}$ & $\begin{array}{l}\text { /tasir/ } \\
\text { /rəsul/ } \\
\text { /mənsəb/ }\end{array}$ & $\begin{array}{l}\text { 'effect' } \\
\text { 'prophet' } \\
\text { 'position' }\end{array}$ \\
\hline$|\mathrm{z}|$ & $\begin{array}{l}<j> \\
<_{j}> \\
<_{j}> \\
<\dot{b}>\end{array}$ & $<\bar{ज}>$ & 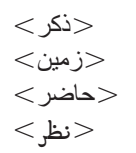 & $\begin{array}{l}<\text { ज़िक्र }> \\
<\text { ज़ीन }> \\
<\text { हाज़िर }> \\
<\text { नज़र }>\end{array}$ & $\begin{array}{l}\text { /zıkr/ } \\
\text { /zəmin/ } \\
\text { /hazır/ } \\
\text { /nəzər/ }\end{array}$ & $\begin{array}{l}\text { 'mention' } \\
\text { 'earth' } \\
\text { 'present' } \\
\text { 'gift' }\end{array}$ \\
\hline$/ \mathrm{h} /$ & $\begin{array}{l}<_{\tau}> \\
<_{0}>\end{array}$ & $<$ ह $>$ & > بمكت>>> > > > > & $\begin{array}{l}<\text { हिकमत }> \\
<\text { हिम्मत }>\end{array}$ & $\begin{array}{l}\text { /hikmot/ } \\
\text { /himmət/ }\end{array}$ & $\begin{array}{l}\text { 'wisdom' } \\
\text { 'courage' }\end{array}$ \\
\hline$/ \mathrm{t} /$ & 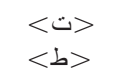 & $<$ त $>$ & $\begin{array}{l}>> \\
>> \\
>\end{array}$ & $\begin{array}{l}<\text { किताब }> \\
<\text { ख़िताब }>\end{array}$ & $\begin{array}{l}\text { /kitab/ } \\
\text { /xitab/ }\end{array}$ & $\begin{array}{l}\text { 'book' } \\
\text { 'address' }\end{array}$ \\
\hline
\end{tabular}

these phonemes correctly, other Urdu speakers often comment that they have not gotten their fin and qaf correct - referring to two of the letters of the Urdu alphabet. In fact, the correct pronunciation of these sounds is so iconic of the "authentic" Urdu speaker that even Mohammad Iqbal (1877-1938), who is considered to be one of the tallest figures of Urdu poetry, was ridiculed by Urdu speakers for not being able to pronounce them correctly. Iqbal was from the province of the Punjab and, like most Punjabi-Urdu speakers, pronounced qaf, the phoneme /q/, as $k a f, / k /$.

During my fieldwork, I came across some articles in Urdu newspapers that lament the loss of the phonemes among young Urdu speakers and equate it with the loss of the Urdu language. In an article published in the Rashtriya Sahara, one writer gives specific examples of how the Urdu phonemes /q/ in words such as /diqqat/ 'trouble' and / $\mathrm{x} /$ as in /xərtfa/ 'expenditure,' are being pronounced incorrectly as [drkkət] and [ $\mathrm{k}^{\mathrm{h}}$ ərtfa] by the younger generation (W. Rahman 2006). He appeals to Urdu speakers to make sure that they pronounce them correctly.

Since these phonemes are not Indic, Devanagari does not have graphemes for them. In Urdu-in-Devanagari they are represented with a diacritic dot-a bindiplaced under Devanagari graphemes. For example, a bindi is placed under the Hindi grapheme $<\overline{\mathrm{h}}><\mathrm{p}^{\mathrm{h}}>$, which stands for the phoneme $/ \mathrm{p}^{\mathrm{h}} /$ to represent the Urdu phoneme /f/. Table 2 below shows the original Devanagari graphemes and the modified ones to represent the distinctive Urdu phonemes.

Although the use of the bindi for representing the distinctive Urdu phonemes has been available since the nineteenth century, it has been historically contested. In 1930, Madan Mohan Malaviya, a very prominent Hindu leader and a staunch supporter of Hindi, wrote an editorial in his weekly newspaper Abhyudaya entitled "hIndi mẽ brndi kyõ?" 'Why use bindi in Hindi?', arguing against the use of the 
TABLE 2. Devanagari graphemes and their modifications. $[$ colcnt $=4]$

\begin{tabular}{lccc}
\hline \hline $\begin{array}{l}\text { Distinctive Urdu } \\
\text { phoneme }\end{array}$ & $\begin{array}{c}\text { Closest Hindi } \\
\text { phoneme }\end{array}$ & $\begin{array}{c}\text { Devanagari } \\
\text { grapheme }\end{array}$ & $\begin{array}{c}\text { Modified bindi } \\
\text { grapheme }\end{array}$ \\
\hline$/ \mathrm{f} /$ & $/ \mathrm{p}^{\mathrm{h} /}$ & $<\mathrm{W}>$ & $<$ फ़ $>$ \\
$/ \mathrm{z} /$ & $/ \mathrm{d} /$ & $<\mathrm{G}>$ & $<$ ज़ $>$ \\
$/ \mathrm{x} /$ & $<\mathrm{k} /$ & $<$ ख़ $>$ \\
$/ \mathrm{b} /$ & $/ \mathrm{g} /$ & $<\mathrm{J}>$ & $<$ ग़ $>$ \\
$/ \mathrm{q} /$ & $/ \mathrm{k} /$ & $<\mathrm{T}>$ & $<$ \\
\hline \hline
\end{tabular}

diacritic in Hindi for the distinctive Urdu phonemes (Mehrotra 2005). In practice also, the bindi diacritic is not used in Hindi publications.

It is interesting to note that in Hindi the bindi is used over some graphemes to represent nasal consonants and nasalized vowels, for example, < चंद्र $>$ [təondr] 'moon' and $<$ माँ $>$ [mã] 'mother'. The diacritic is also used underneath some graphemes to represent retroflex sounds, for example, $<$ s $>, / \mathrm{r} /$ and $<ढ>/ \mathrm{r}^{\mathrm{h}} /$. So the issue is more ideological than technological. Shahid Amin, a renowned Muslim historian, describes his frustration with Hindi publishers regarding the use of the bindi: "I have written a little bit in Hindi and every time it [the manuscript] comes back from the publisher all the bindis have systematically been taken off" (Mehrotra 2005:189). Many of my Muslim research participants were unhappy that their Hindu friends did not place a bindi under the Hindi graphemes for the distinctive Urdu phonemes in their names.

The practice of not using bindis for the distinctive Urdu phonemes can be seen in Hindi books, magazines, and newspapers published from India. None of the most widely read Hindi newspapers use a bindi for these phonemes. I studied five online newspapers published from North India, including Dainik Jagran and Dainik Bhaskar, which, according to the 2006 report of the National Readership Studies Council, recorded the highest readership among all newspapers published in India. Dainik Jagran and Dainik Bhaskar, published simultaneously from several cities in North India have a readership of 21.2 and 21 million respectively. ${ }^{16}$

The following extract from Dainik Jagran shows that although the newspaper uses some words containing these phonemes, the bindi is not used to represent them. ${ }^{17}$ The phonemes / $\mathrm{x} /, / \mathrm{z} /, / \mathrm{f} /$, and /q/in the words $<$ खालिदा $><\mathrm{k}^{\mathrm{h}}$ alida $>$, $<$ जिया $><$ काya $>$, < माफी $><$ mafi $>$, and $<$ तारिक $><$ tarik $>$ are not marked with the bindi diacritic. To help the reader identify these graphemes, the words containing them are bolded in the example below.

(2) खालिदा जिया के बेटे ने आरोप स्वीकारा ढाका। हिरासत में रखे गए बांग्लादेश की पूर्व प्रधानमंत्री खालिदा जिया के बड़े बेटे तारिक रहमान ने भष्टाचार में शामिल होने की बात स्वीकार करते हुए इसके लिए माफी मांगी है। 
... रहमान खालिदा की बांग्लादेश नेशनलिस्ट पार्टी (बीएनपी) के संयुक्त महासचिव हैं। उन्हें ढाका छावनी इलाके में स्थित उनकी मां के घर से गिरफ्तार किया गया था। बाद में उन्हें खुफिया एजेंसयों के हवाले कर दिया गया।. ${ }^{18}$

In contrast to the convention prevalent in Hindi language newspapers, publications in Urdu-in-Devanagari represent the distinctive Urdu phonemes with the bindi diacritic quite religiously. Both Anchal and Ahadis are categorical in the representation of the distinctive Urdu phonemes using the bindi diacritic. Given below is the contents page of the July 2005 issue of Anchal.

Each line in the extract contains the distinctive phonemes represented by the bindi diacritic, circled above for better visual clarity. For example, the very first line below the heading contains two distinctive Urdu phonemes /q/ and /z/ in the words <मुक़ाबला > < muqabla > 'competition' and <जबान > < zəban > 'tongue', and both have been marked with the bindi diacritic. Other examples are /f/ in the word <अफ़साने $><$ əfsane $>$ 'stories', /z/ in < ज़ायक़े $><$ zaeqa $>$ 'taste', $/ \mathrm{x} /$ in the word $<$ ख़ास $><$ xas $>$ 'special', $<_{\boldsymbol{B}}>$ in the word $<$ bəzlẽ $>$ $<$ ग़जलें $>$ 'poetry', and /q/ in $<$ qimət $><$ क़ीमत $>$ 'value'.

The use of the bindi diacritic makes Ur-Nag texts visually distinguishable from Hindi texts. I argue that in the absence of the Arabic script, the bindi serves as an orthographic contextualization cue for readers that the text in question is Urdu and not Hindi; the bindi has now become invested with the meaning that was indicated by the Arabic script before.

\section{The representation of the Urdu graphemes baRi he $<_{\tau}>$ and ain $<\varepsilon>$}

The principle of orthographic transliteration to create distance and distinctions from Hindi is evidenced in the representation of two Urdu graphemes baRi $h e\left\langle_{\tau}>\right.$ and ain $\left\langle_{\varepsilon}>\right.$. These are two of the phonemically empty graphemes of the Urdu alphabet. Since these graphemes do not have corresponding phonemes, there do not seem to be any linguistic reasons why they should be represented. However, my data shows that they are represented in Devanagari, although not as categorically as the distinctive phonemes.

As shown in Table 1, the Urdu phoneme $/ \mathrm{h} /$ is represented by the grapheme $b a R i$ $h e\left\langle_{\tau}>\right.$ and chhoTi he $\left\langle_{\mathrm{0}}\right\rangle$, which stand for $/ \mathrm{h} /$ and $/ \mathrm{h} /$ in Arabic. Since Urdu does not make a phonemic distinction between $/ \mathrm{h} /$ and $/ \mathrm{h} /$, baRi he is not pronounced, although it is preserved in Urdu orthography. In Urdu-in-Devanagari, both of these graphemes are represented generally by the grapheme $\langle$ ह $>$. In some texts, however, baRi he is represented differently from chhoTi he by placing the bindi diacritic underneath $<$ ह $>$. Table 3 gives examples of words containing baRi he with and without the bindi diacritic.

The variation in the representation of baRi he is related to the genre of the text. In Anchal, which largely contains secular texts, baRi he is NEVER represented with the 
TABLE 3. Variation in the representation of baRi he $<_{\tau}>$. $[\operatorname{colcnt}=6]$

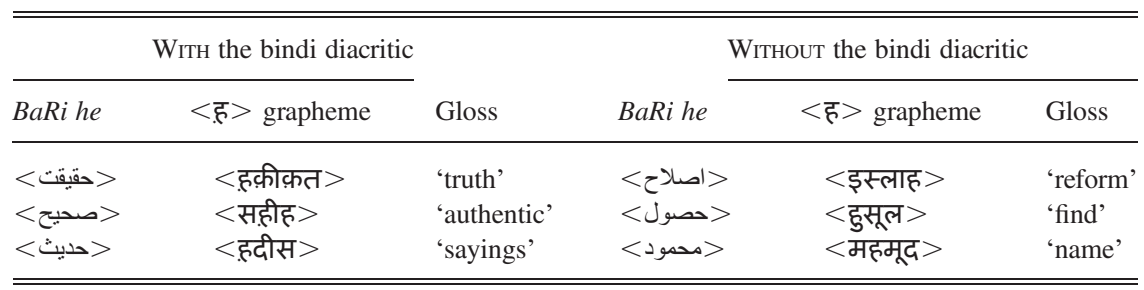

bindi diacritic. In Ahadis, which is a religious text, however, words containing baRi he are often written with the bindi diacritic, although with some variation. This suggests that the ideologies of the people involved in the process of transliteration of religious texts are more conservative. This may be motivated by their desire to preserve in Devanagari, as much as possible, the Urdu-ness of the original text. This could also be a strategy to command religious credibility and authority of the Devanagari texts. Since the difference between these graphemes is not phonemic, only people of religious learning have access to the historical spelling of words containing baRi he. Here one can see the use of orthographic transliteration as a resource to construct authority and credibility.

Another example of the use of orthographic transliteration to create distinctions and distance is the representation of ain $\left\langle_{\varepsilon}>\right.$ in Devanagari. The letter ain in Arabic stands for the pharyngeal fricative consonant/S/. In Urdu, ain does not have a corresponding phoneme; in some contexts, however, it influences the pronunciation of the preceding vowel. Muslims have chosen the Devanagari schwagrapheme $\langle अ>$ to represent ain. Before discussing the innovation and the impact it has on the graphotactics of Devanagari, I give some possible reasons why $\langle$ अ $\rangle$, a vowel-grapheme, has been chosen for ain, which is a consonant.

Unlike Arabic, the letter ain is not pronounced in Urdu in word-initial and wordfinal positions. Many old manuscripts, written in the Arabic script from as late as the seventeenth century, show spellings in which word-final ain is dropped. In his classic book Sabras Mulla Wajhi, a seventeenth century Urdu poet from Deccan, spells words such as $\langle$ وضع > wəzaS> 'look' and > نفع > mənaA> 'benefit' without the final ain (Shirani 1966:260-61). In later developments of Urdu, the letter ain in such words was restored in order to conform to the original Arabic spellings. The data in Table 4 show the zero pronunciation of ain in wordinitial and word-final positions.

In word-medial positions, however, although ain is not pronounced, it impacts the pronunciation of the preceding vowel by making it long. This is similar to the wellknown linguistic phenomenon of compensatory lengthening.

This may give a false impression that ain is vowel-like. This probably is the reason why Urdu speakers have chosen $\langle$ अ $>$ to represent the consonant ain. This additional use of the schwa-grapheme, in addition to its normal use as 
TABLE 4. Zero pronunciation of ain. $[$ colcnt $=5]$

\begin{tabular}{|c|c|c|c|c|}
\hline Urdu & Spelling & IPA & Gloss & Phonemic value \\
\hline > عرض>> & $<$ fərz $>$ & [ərz] & 'offer' & $\mathrm{q}>\phi$ \\
\hline > عمر > & $<$ Gumr $>$ & [omr] & 'age' & $\hat{\uparrow}>\phi$ \\
\hline >وسيع>> & $<$ wasif $>$ & [wəsi] & 'wide' & $\oint>\phi$ \\
\hline > موضوع>> & $<$ mauzuS $>$ & [mauzu] & 'topic' & $\mathrm{\varphi}>\phi$ \\
\hline
\end{tabular}

TABLE 5. Compensatory lengthening of vowels due to ain. [colcnt $=5]$

\begin{tabular}{|c|c|c|c|c|}
\hline Urdu & Spelling & Pronunciation & Gloss & Phonetic value \\
\hline > نعت > & $<\mathrm{n} ə \mathrm{it}>$ & [nat] & ‘eulogy’ & $\partial \mathrm{S}>\mathrm{a}$ \\
\hline > بعد> > & $<$ buid $>$ & [bod] & 'distance' & $U S>0$ \\
\hline >نعمت > & $<$ nIImat $>$ & [nemat] & 'blessing' & If $>\mathrm{e}$ \\
\hline
\end{tabular}

schwa, however, conflict with each other. In order to understand the conflict, it is necessary to discuss briefly some properties of Devanagari.

\section{Devanagari alphabet}

An important feature of the Devanagari writing system is that all consonant-graphemes have an inherent schwa in them, and therefore there is no need to write it separately from the consonants. For example, the grapheme $<$ क $>$ stands for $/ \mathrm{k} /$, the consonant $/ \mathrm{k} /$, and the schwa $/ \partial /$. A consequence of this is that the schwa-vowel $\langle$ अ $>$ is written only word-initially, for example in words such as $<$ अचेत $>$ [ətfet] 'unconscious', <अकाल $>$ [əkal] 'famine'. All other vowels have two allographs, positional variants - one is free and the other is bound. The free allograph is only used in word-initial positions; the bound one, which must occur with a consonant, is used word-medially and word-finally.

Table 6 gives examples of some Hindi vowels and their positional variants with the consonant $<$ क $><\mathrm{k} ə>$, as an example.

Notice that there is no bound form for the schwa-grapheme $<$ $>$ (since it is assumed to be part of consonant graphemes). This feature of Devanagari allows one to write many words of Hindi without writing vowels overtly, for example, the word [kəməl] 'flower' can be written just by writing the consonant graphemes $<$ क $>,<$ म $>$, and $<$ ल $>$, one after another as $<$ कमल $>$. This is of course not possible if the word contains vowels other than schwa.

The use of the schwa-grapheme $<अ>$ to represent the Urdu letter ain $<\varepsilon>$ conflicts with its original use as a symbol for the vowel schwa /ə/. I mentioned above that the distribution of the schwa-grapheme $\langle$ अ $\rangle$ in Devanagari is limited to the word-initial position. The Urdu letter ain $\left\langle_{\varepsilon}>\right.$, however, is not 
TABLE 6. Positional variants of some Devanagari vowels. $[$ colcnt $=5$ ]

\begin{tabular}{|c|c|c|c|c|}
\hline Free form & Bound form & IPA & With $<$ क $><$ k $>$ & IPA \\
\hline$<$ अ $>$ & None & /a/ & क & /kə/ \\
\hline$<$ आ $>$ & ा & /a/ & का & $/ \mathrm{ka} /$ \\
\hline$<इ>$ & ि & $/ \mathrm{I} /$ & कि & $/ \mathrm{kI} /$ \\
\hline$<ई>$ & ी & /i/ & की & $/ \mathrm{ki} /$ \\
\hline
\end{tabular}

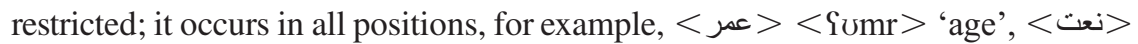
<nəSt> 'eulogy', and > حوسيع> < > wəsiS> 'wide'. The word-initial ain fits well with the occurrence restriction of $\langle$ $\rangle\rangle$ in Devanagari, and therefore it is written like other words. The ain in word-medial and word-final positions however does not agree with the distributional restriction of $\langle$ अ $\rangle$, which is that it can only occur word-initially.

However, this rule of standard Devanagari is flouted by writers of Urdu-in-Devanagari in order to ensure that ain is represented. Table 7 shows examples of words taken from Anchal and Ahadis containing the schwa-grapheme $<$ अ $>$ in wordmedial and word-final positions, shown in columns 2 and 5 respectively. Both the word-medial and word-final occurrences of $\langle$ अ $\rangle$ are unlicensed because a schwa-grapheme is never written word-medially or word-finally in standard Devanagari orthography.

However, for Urdu-in-Devanagari writers, the schwa-looking grapheme in Table 7 is not the regular (Hindi) schwa but the Urdu consonant ain. Urdu speakers have reanalyzed $\langle$ अ $>$ as a symbol for both the schwa-vowel and the consonant ain.

In order to ascertain that the use of the schwa-grapheme in word-medial and word-final positions indeed violates the basic properties of Devanagari, I conducted research among Hindi speakers, all of whom were Hindu except one. I administered a survey to nineteen students doing their Master's degree in the Hindi language and literature at Jawaharlal Nehru University, New Delhi. The reason for selecting graduate students was that writing is a learned skill, and therefore students studying Hindi are more likely to be aware of the writing conventions than ordinary speakers of Hindi.

The goal of the survey was to understand how the innovations introduced into Devanagari by Urdu speakers are perceived by Hindi speakers. One of the questions

TABLE 7. Word-medial and word-final use of अ. [colcnt $=6$ ]

\begin{tabular}{|c|c|c|c|c|c|}
\hline Urdu & Ur-Nag & Gloss & Urdu & Ur-Nag & Gloss \\
\hline >نعت> > & $<$ नअत्र $>$ & ‘eulogy' & >وسيع>> & < वसीअ > & 'wide' \\
\hline > تعلقق > & $<$ तअल्ल्लक $>$ & 'relation' & >نوسيع>> & $<$ तौसीअ $>$ & 'expansion' \\
\hline > معنى> & $<$ मअंनीं> & 'meaning' & > موضوع>> & $<$ मौज़ू $\overline{\text { T }}>$ & 'topic' \\
\hline
\end{tabular}


in the survey was whether they had seen words containing the schwa-grapheme word-medially and word-finally, such as $<$ नअत $>$ and $<$ वसीअ $>$, in print before. The result of the survey shows that $75 \%$ or more of the respondents had NOT seen such words before. This suggests that Hindi speakers are not aware of the innovations introduced by Muslims in the Devanagari script.

The second question was if the spellings of the Urdu-in-Devanagari words containing word-medial and word-final schwa were correct according to standard Devanagari conventions. A majority of the respondents judged such words to be incorrect. In response to the question why they thought the word was written incorrectly, most respondents wrote that in Hindi $\langle$ अ $>$ is never written after a consonant. Vikas, one of the respondents expressed this convention very clearly: "In the Devanagari script, a vowel is not written in an independent form in the middle of consonants. The vowel $\langle$ अ $\rangle$ is already inherent in consonants, and therefore there is no need to write it separately."

It is worth pointing out that this unlicensed use of ain makes the pronunciation of such words abstruse to Hindi speakers, because of the "awkward" graphemic clusters. In such cases, it becomes impossible for them to predict the pronunciation based on the written representation. I asked the participants how they would pronounce the words containing the schwa-grapheme in word-medial and word-final positions. For the word $<$ नअत $><$ nəSt $>$, which is pronounced in Urdu as /nat/, a one-syllable word, taking a cue from the orthography, a majority of them said that they would pronounce it as /nə.ət/, as if it had two syllables. Some of them also said that they did not know how to pronounce it at all. Similarly, for the word $<$ vasif $>$, a two-syllable word, which is pronounced in Urdu as /və.si/, a majority of them indicated that they would pronounce it as /və.si.ə/ as if it were a three-syllable word.

The data discussed above suggest that Urdu speakers and writers violate the orthographic constraints of Devanagari in order to preserve the orthographic features of Urdu. Although the letter ain is not pronounced in Urdu in many positions, Urdu speakers still wish to represent it because they would like to transfer the orthographic features of Urdu into Devanagari regardless of their phonemic significance or lack of it. Motivated by the desire to preserve the orthographic integrity of the Urdu language, Urdu speakers have reanalyzed the Devanagari schwa-grapheme in such a way that it stands for both the schwa-vowel and the Urdu consonant ain. In other words, Muslims have turned the schwa-grapheme into a homograph-two graphemes that have the same orthographic shape. If we adopt this hypothesis, then what appears to be a violation of standard Devanagari conventions no longer remains so.

The evidence in support of the claim comes from the practice of using hal/viram, the "vowel killer" diacritic. A hal is used in Devanagari to eliminate the schwavowel inherent in each consonant grapheme. For example, the grapheme $<$ क $>$ stands for [kə], but if a hal is placed under it, as in $<$ क् $>$, the schwa is eliminated; it now stands only for the consonant $[\mathrm{k}]$. If Urdu speakers have reanalyzed the 
TABLE 8. अ with hal. [ colcnt $=8]$

\begin{tabular}{|c|c|c|c|c|c|c|c|}
\hline $\begin{array}{l}\text { Word-medial } \\
<अ>\end{array}$ & $\begin{array}{c}\text { Arabic } \\
\text { script }\end{array}$ & Roman & Gloss & $\begin{array}{c}\text { Word-final } \\
<\text { अ }>\end{array}$ & $\begin{array}{c}\text { Arabic } \\
\text { script }\end{array}$ & Roman & Gloss \\
\hline वसीअ्तर & وسيع تر & wəsiStər & 'wider' & मौज़ूअ् & موضوع & məuzuS & 'topic' \\
\hline मअदूम & معدوم & məSdum & 'extinct' & मनाफ़ेअ & منافع & mənafis & 'benefit' \\
\hline तअंदील & تعديل & təSdil & 'change' & तवाज़अ् & تو اضع & təwazos & 'humility' \\
\hline
\end{tabular}

schwa-grapheme as a symbol for the consonant ain, then we should find instances where a hal is placed on $\langle$ अ $>$. This indeed is the case. The examples in Table 8 taken from Ahadis support this. Column 1 shows words containing $<$ अ $>$ wordmedially with a hal undeneath it. Column 4 shows words containing $<$ अ $>$ word-finally with a hal undeneath it.

The use of hal clearly suggests that this $<$ अ $>$ is not the schwa grapheme; it is the consonant grapheme ain. So, if $\langle$ $>>$ is replaced with any consonant grapheme in the above examples, the resulting words would be correct graphotactically. Another reason why $\langle$ अ $>$ in the above examples must be a consonant grapheme is that hal is not used on the schwa-grapheme. It won't make sense to write a schwa-vowel and then get rid of it by placing a hal-vowel-killer-on it.

The representation of ain, unlike the distinctive phonemes discussed above shows some variations. Two of them are worth noting. For example, the word

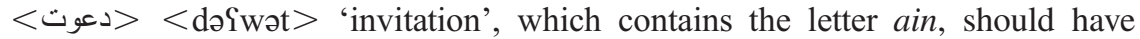
been written like <दअवत> with the schwa in the middle for ain, but it is written like any other Hindi word with a long vowel $<$ दावत $>$. This means that authors use the orthographic and phonetic transliterations inconsistently in representing the letter ain. This variation is typical of any emerging, yet-to-stabilize orthographic practice (see e.g. Palfreyman \& al-Khalil 2003; Androutsopoulos 2009).

The second variation is more interesting because it is related to the genre of the text. In Ahadis, which is a religious text, the schwa-grapheme for ain is marked with an additional bindi diacritic underneath, similar to the representation of baRi he, to distinguish it from $\langle$ $\langle>$, the vowel-grapheme. Remember that in Urdu-in-Devanagari in general, the schwa-grapheme is a homograph for the schwa and the consonant ain. In Anchal, for example, the word-initial occurrence of ain $<$ अ $>$ is not different from the schwa-vowel occurence. In Ahadis many occurences of the letter ain are additionally marked with the bindi diacritic under $<$ अ $>$. Table 9 gives some examples comparing Anchal and Ahadis. Notice that column 1 has $<$ अ $>$ without the bindi, whereas column 2 has bindi-modified $\langle$ अ $\rangle$.

The above examples suggest that religious texts reveal a more conservative approach to transliteration than secular ones. Like baRi he, this may be a strategy to command religious credibility and authority of the Devanagari texts. Remember that Devanagari traditionally has been associated with Hinduism and therefore 
TABLE 9. Variation in the representation of ain. [colcnt $=4]$

\begin{tabular}{llll}
\hline \hline Anchal & Ahadis & Spelling & Gloss \\
\hline$<$ जमाअत $>$ & $<$ जमाअत $>$ & $<$ bəmafət $>$ & 'group' \\
$<$ अमल $>$ & $<$ अमल $>$ & $<$ Fəməl $>$ & 'work' \\
$<$ इआनत $>$ & $<$ इआनत $>$ & $<$ Ianət $>$ & 'help' \\
\hline \hline
\end{tabular}

the writers of Urdu-in-Devanagari must feel the pressure to make it look different from Hindi and assert that the text in Devanagari is as credible as the one written in the Arabic script. Again, the orthographic transliteration is used as a resource to construct authority and credibility.

To sum up, it is clear from this discussion that Urdu speakers are innovating strategies to mark Urdu-in-Devanagari as distinct from Hindi. I discussed two such major strategies: (i) the use of phonetic transliteration as a strategy to represent the distinctive Urdu phonemes, and (ii) the use of orthographic transliteration as a means of representing the Urdu letter ain and baRi he. If my claim about Urdu-in-Devangari as being distinct from Hindi is valid, then we should find evidence from those who are involved in the production and consumption of Urduin-Devanagari texts.

Data from Anchal suggests that the readers and publishers both believe that the language of the magazine is indeed Urdu. The co-editor of the magazine, Talib Rampuri, writes a column entitled zəban (Urdu) svd $\mathrm{d}^{\mathrm{h}}$ are "Improve your language (Urdu)' quite frequently. This column publishes a list of "mispronounced" or "misspelled" Urdu words with their correct pronunciation or spelling and meanings provided by the editor. Obviously, the Urdu words and their meanings are all written in Devanagari, but the assumption of the editors, indicated by the title, is that through that column, readers can improve their knowledge of Urdu. In fact, many readers in their letters to the editor acknowledge that they are either learning Urdu by reading the magazine or that their knowledge of Urdu is improving. Vasant Kumar, a reader from Munger in the state of Bihar who is most likely to be a Hindi speaker, writes, 'Sister! I love poetry, and that is why in order to learn Urdu and improve my language, I have been regularly reading Mahakta Anchal and Khubsurat Andaz for many years. My problem is that none of my ghazals have been selected for publication...' (Kumar 2005:76). Similarly, another reader, Malti Devi, in the April 2006 issue wrote to the editor that she is learning Urdu by reading Anchal.

In fact, the editors of the magazine suggest that those who are interested in learning Urdu correctly should benefit from the magazine. In response to an angry letter from a reader who was disappointed with the use of the Urdu plural markers /ẽ/ and /õ/ on the English loanword 'letter', the editor explains the reason for the use of Urdu suffixes on English loanword by arguing that the beauty of Urdu lies in the diversity of its words and phrases. She further argues that Urdu is quite generous and welcomes words and expressions from other languages, and then she suggests 


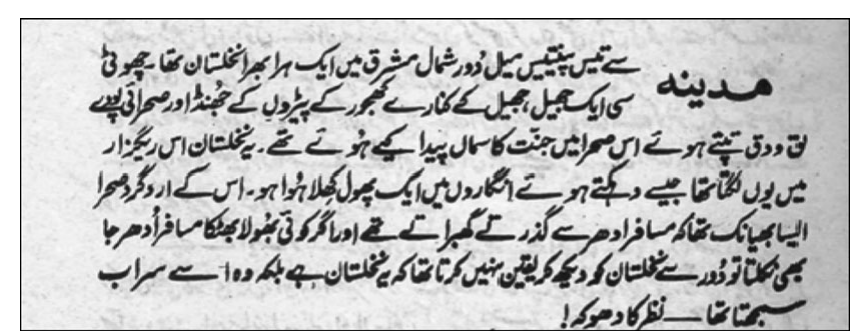

FIGURE 1. Urdu in the Arabic script.

that those who are interested in learning Urdu should read Mahakta Anchal regularly.

Another piece of evidence comes from Sukaina, a young woman from Old Delhi, who reads Fazael-e-Amal, another religious book transliterated into Devanagari. ${ }^{19}$ She represents the younger generation of Muslims who disaffiliate from Urdu and the symbolic meaning it carries. In an interview, when I asked her about the language of the transliterated version of Fazael-e-Amal, she said, "bolne mẽ to wo Urdu hi hæ, lekın dek ${ }^{\mathrm{h}}$ ne mẽ hindi hai" 'it is Urdu when you speak it, but it looks Hindi [on paper]'. To Sukaina, despite the change of scripts, the language of the book remains Urdu.

The last piece of evidence that supports my claim comes from Mohammad Suhaib, a middle-aged man who was born and raised in Old Delhi. He is self-employed as a publisher of Urdu books. When his publishing work is dull, he also does transliteration from the Arabic script into Devanagari. He has transliterated many literary works including a number of novels based on Islamic history such as The storm of Hejaz, from which I give an extract in Figs. 1 and 2 and in (1). Our conversation about the language of the transliterated novel is shown below in (3).

(3) MS: Mohammad Suhaib, RA: author

MS: to Usko sirf convert kıya hæ hindi mẽ.

'So, (we) have just converted it into Hindi.'

RA: $\quad \operatorname{tg}^{\mathrm{h}} \mathrm{a}$.

'OK.'

MS: Is mẽ koi changing nəhĩ ki hæ həm ne.

'We have not made any changes to it.'

RA: $\quad$ tg $^{\text {h }}$ a koi changing nəhĩ ki hæ?

'You have not made any changes?'

MS: koi changing nəhĩ ki hæ Is mẽ!

'We have not made any changes to it!' 
मदीना से तीस-पैंतीस मोल दूर शिमाल मशिरक में एक हरा-भरा नख़्लिस्तान था। छोटी सी एक झील, झील के किनारे खजूर के पेड़ों के झुंड और सेहराई पौदे लको-दक तपते हुए इस सहरा में जन्नत का समां पैदा किए हुए थे। यह नख़्लिस्तान इस रेगज़ार में यूं लगता था जैसे दहकते हुए अंगारों में एक फूल खिला हुआ हो। उसके इर्द-गिर्द सेहरा ऐसा भयानक था कि मुसाफ़ि इधर से गुज़रते घबराते थे और अगर कोई भूला भटका मुसाफ़िर इधर जा भी निकलता तो नख़्लिस्तान को देख कर यकीन नहीं करता था कि यह नख़्लिस्तान है बल्कि वह इसे सराब समझता था। नज़र का धोका!

\section{जुलाई 2005 की झलक}

- मुक्किबला लव लेटर - दिल की ज़ानान - इनआमी डायलाग - नाविल • नाविलिट • कहानियां • अफुसाने - एकातें - मेकअप - गुनगुनाती दोस्ती • में और मेरा दोस्त • वाह क्या शैअर है • जाएके

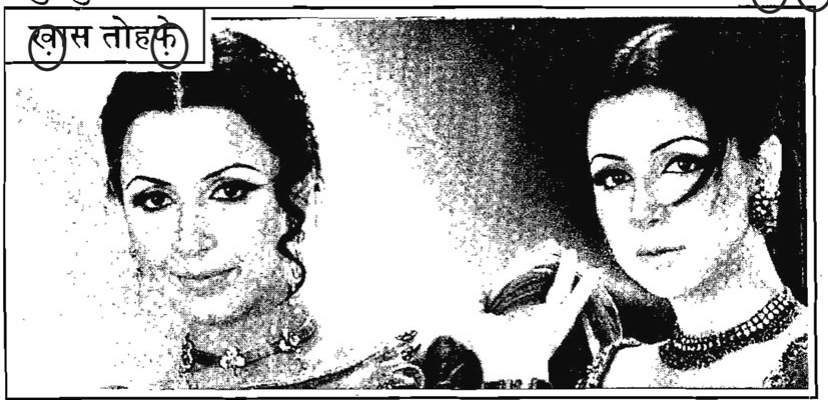

सिलसिलेवार नाविल :-

- खुशबू है हम सफ़र (रिफ़अ सिराज)

- धूप छांव (इक़रा एस अहमद)

- तेरी खुशी की खातिर (इक़रा एस. अहमद) मुकम्मल नाविल, नाविलिट, कहानियां

- मुझे कुछ नहीं चाहिए (निगहत अब्दुल्लाह)

- इस शहरे मुहब्बत में (नाज़िया कंवल नाज़ी)

- तुम एक चराग (समरा बुखारी)

- ख़्वाहिशों के शहर में (आमना नसीम)
- अन्धेरों के मुसाफ़िर (हुमेरा राहत)

- मैं तुम से मुहब्बत करता हूं (रूख़ चौधरी)

- जादू उतर गया (नबिय नकीवी)

- भरपाई (बुशरा अहमद)

- तुम हंसती अच्छी लगती हो (फ़रहत इश्तियाक़)

- हुस्नों सेहत: कीमती टिप्स (डा० आसिया राशिद)

- लीची: गर्मियों का खास फल (शमीम जहां)

- वाह क्या शेअर है! (वसीम बरेलवी)

और बहुत कुछ..

FIGURE 3. Contents page of Mahakta Anchal, July 2005.

Suhaib believes that in doing the transliteration, all he has done is change scripts. Other features of Urdu - for example, the words or the distinctive phonemeswhich to him are arguably more critical than the script, have been preserved in Devanagari. He therefore has no doubts that the language of the text in Devanagari is Urdu. Notice that he holds on to his position even after I turned his statement into a 
question. His ideology about what defines Urdu is drastically different from the traditional view that equates Urdu with the Arabic script.

\section{S U M M A Y A N D D I S C S S I O N}

In this article, I have demonstrated that the adoption of the Devanagari script by Muslims for writing Urdu, which has been written in the Arabic script for several centuries, challenges the traditional view that the choice of script is critical in differentiating Urdu and Hindi. Analyzing the recent orthographic practices of writing Urdu in Devanagari, I show that Muslims in India no longer view the Arabic script as a necessary, let alone defining, element of Urdu, nor do they believe that Devanagari is completely antithetical to Urdu and their Muslim identity. In addition, while Muslims have adopted Devanagari, they have not suspended the difference between Urdu and Hindi. Using the strategies of phonetic and orthographic transliterations, Muslims are making Urdu-in-Devanagari different from Hindi, although the difference is much more subtle and nuanced.

The adoption of Devanagari for writing Urdu clearly demonstrates that the ideologies about the Urdu language and its traditional Arabic script are also undergoing a major transformation. The Arabic script, which hitherto was believed to be THE differentiating element between Urdu and Hindi on the written level, is no longer ideologized as such. The changed socio-political contexts of postcolonial India have contributed to a re-evaluation and revision of what defines the Urdu language. The innovations introduced by Muslims into Urdu-in-Devanagari allow them to rationalize that the text written in Devanagari still remains sufficiently distinct from Hindi. I show that the consistent use of the bindi diacritic and the novel use of the schwa-grapheme as a symbol for the Urdu consonant letter ain make Urdu-in-Devanagari distinct from Hindi.

This article further suggests that the structure of a writing system - its graphemes and the rules that govern how they combine with each other, that is, its graphotactics - are not a mere technical matter of representation of sounds on paper. I argue that the structure of a writing system is in part constituted by social and cultural factors that involve issues of identity. I show that Muslims are modifying the structure of Devanagari by introducing a diacritic called the bindi to represent distinctive Urdu phonemes. They are also trying to preserve orthographic features of Urdu in Devanagari, for example, the "silent" consonant letter ain $\langle\varepsilon\rangle$, which is actually phonemically empty. Although the choice of $\langle\mathcal{Y}\rangle$ for representing ain results in unlicensed graphemic clusters in Urdu-in-Devanagari, Muslims still use it in order to ensure that the silent Urdu letter ain is represented.

The emergence of Urdu-in-Devanagari raises an interesting question. Is this a subcultural phenomenon taking place on the margins of the Muslim society? Will the phenomenon fade away with time or will it stabilize? Linguists do not like to make predictions, especially about sociolinguistic situations. Based on the current practices, however, I strongly believe that the phenomenon will stabilize 
and Urdu will acquire a new outfit in the form of Devanagari. It, however, will undergo a makeover to suit the sociolinguistic needs of Muslims. I further believe that the phenomenon is not marginal because, although Urdu-in-Devanagari is being produced FoR the Muslim youth, others, especially the middle-generation, is involved in the process of transliteration because they master both the Arabic and Devanagari scripts. In addition, by looking at Urdu-in-Devanagari publications, it is clear that both secular and religious texts are being transliterated. In fact, a large number of them are religious texts, including Muntakhab Ahadis and Fazael-e-Amal. The goal of such books is to bring the youth closer to the Muslim culture and heritage at a time when many older Muslims believe that the youth are drifting away from their values and traditions. Urdu-in-Devanagari is thus a means to inculcate compliance to the cultural norms and values rather than their subversion.

Finally, a word about the macro social and political contexts within which the orthographic practices discussed above are taking place is in order. The Indian Constitution not only gives minorities the right to maintain their languages and scripts but also obligates the states and local authorities to provide the necessary support and institutional structure for their maintenance and growth. These constitutional provisions notwithstanding, the Indian government has failed to create conditions - social, political, and educational-in which the language and script of the Muslim minority can survive and flourish. This gap between the beautiful constitutional provisions and the pathetic educational and linguistic realities on the ground clearly indicates that minority languages and scripts can become marginalized and eventually die out in the shadows of the very constitutions that claim to sustain them. 


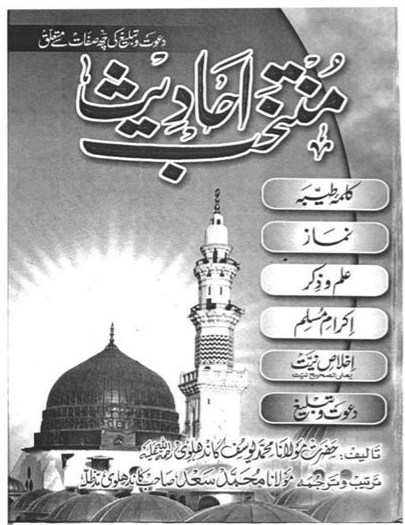

\section{Mahakta Anchal in the Arabic script}

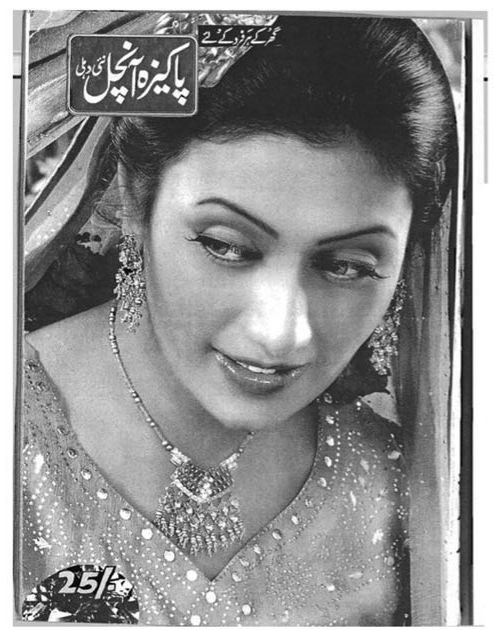

\section{Mahakta Anchal in Devanagari}

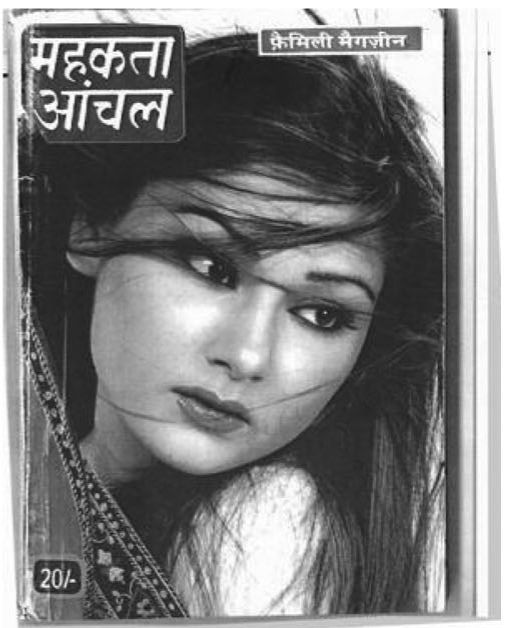

\section{NOTE S}

*I would like to thank Barbara Johnstone and two anonymous reviewers for their feedback on the manuscript. Their comments were extremely helpful in revising the article. Thanks are also due to my colleagues and friends Robin Queen, Barbara Metcalf, Sai Samant, Vibhas Verma, and Lauren Squires for their valuable thoughts on earlier drafts. I would also like to thank my brother Irfan Ahmad whose insights on the social and political life of Indian Muslims have been useful in thinking 
through this article. Thanks are also due to Dr. Rizwanur Rahman of JNU for his help on conducting the script survey at JNU. Finally, I would like thank Pam Beddor, Chair, Department of Linguistics, University of Michigan, for hosting me as a Visiting Scholar, which allowed me access to University resources, without which the revision would not have been easy.

${ }^{1}$ The shape of Urdu letters changes depending on their position in the word; the shape given here is the isolated form.

${ }^{2}$ See Ahmad (2008b) for the multiplicity of indexicality of Urdu in India.

${ }^{3}$ In many registers, however, they can become quite incomprehensible. See Russell (1999).

${ }^{4}$ I do not include the phoneme /3/ since it only occurs in a handful of literary words borrowed from Persian.

${ }^{5}$ In the past, Sanskrit was written in many scripts including Brahmi, Kharoshthi, and Bengali.

${ }^{6}$ See the title pages of the texts in the appendix.

${ }^{7}$ In North India, most names clearly reveal the ethnic identities of Muslims and Hindus.

${ }^{8}$ Hadith refers to the sayings of Prophet Mohammad.

${ }^{9}$ Hadis is the Urdu variant of the Arabic word Hadith. The plural of the word is Ahadis.

${ }^{10}$ Some important textbooks are Yates (1836), Ranking (1895), A. Rahman (1923), and Sharma (1937).

${ }^{11}$ See Shahabuddin's (1999) opposition to the adoption of Devanagari in his response to Russell's article.

${ }^{12}$ Unless otherwise noted, all translations are mine.

${ }^{13}$ Although works of some famous Urdu poets such as Ghalib (1797-1869) and Mir Taqi Mir (17231810) have been rendered into Devanagari in the past, the practice of using Devanagari for writing Urdu on a large scale is quite recent in India. Urdu magazines and general books were never published in Devanagari before.

${ }^{14}$ This is not inevitable though; Muslims have made a choice not to represent these letters in Devanagari. The journal The Annual of Urdu Studies uses a transliteration system that has a one-to-one mapping of Urdu letters, including phonemically empty ones, into Roman.

${ }^{15}$ Beesley (1998) considers this transcription rather than transliteration, because it does not involve one-to-one mapping of letters from the Arabic to Devanagari script. Following Androutsopoulos (2009), however, I use the term 'transcription' for the representation of speech on paper and 'transliteration' for the conversion of graphemes from one script to another.

${ }^{16}$ The key Findings of the National Readership Studies Council 2006 can be found on the website of The Hindu: http://www.hindu.com/nic/nrs.htm (accessed May 15, 2007).

${ }^{17}$ Many news websites published from outside of India show conflicting norms regarding the use of the bindi. The BBC Hindi service uses the bindi to represent Urdu sounds, whereas the Voice of America website does not.

${ }^{18}$ This example was taken from the 2007 article खालिदा जिया के बेटे ने आरोप स्वीकारा [Khalida Zia's son confessed charges] in The Dainik Jagran Kanpur. Online: http://www.jagran.com/news/details. aspx?id=3388443 (accessed May 20, 2007).

${ }^{19}$ Fazael-e-Amal is considered to be a vade mecum of the Islamic movement of spiritual renewal called Tablighi Jama'at. See Metcalf (1993) and Masud (2000) for more about the movement.

\section{R E F E R E N C E S}

Kumar, Vasant (2005). Ap kyon pareshan hain. Mahakta Anchal 76.

Ahmad, Rizwan (2008a). Scripting a new identity: The battle for Devanagari in nineteenth century India. Journal of Pragmatics 40:1163-183.

(2008b). Unpacking indexicality: Urdu in India. Proceedings of the Symposium About Language and Society (SALSA). In Amy Brown \& Josh Iorio (eds.), Texas linguistic forum, vol. 52, 1-9. Austin: University of Texas. Online: http://studentorgs.utexas.edu/salsa/proceedings/2008.html; accessed February 7, 2011. 


\section{URDU IN DEVANAGARI}

1033

1034

1035

1036

1037

1038

1039

1040

1041

1042

1043

1044

1045

1046

1047

1048

1049

1050

1051

1052

1053

1054

1055

1056

1057

1058

1059

1060

1061

1062

1063

1064

1065

1066

1067

1068

1069

1070

1071

1072

1073

1074

1075

Altamash, Enayatullah (2005). Hejaz, ki Andhi. Delhi: Adabi Duniya.

Androutsopoulos, Jannis K. (2000). Non-standard spellings in media texts: The case of German fanzines. Journal of Sociolinguistics 4:514-33.

(2009). 'Greeklish': Transliteration practice and discourse in the context of computer-mediated digraphia. In Alexandra Georgakopoulou \& Michael Silk (eds.), Standard languages and language standards: Greek, past and present, 221-49. Furnham: Ashgate.

Bakhshi, S. R., \& Suresh K. Sharma (1995). Delhi through ages. New Delhi: Anmol Publications.

Balhorn, Mark (1998). Paper representations of the non-standard voice. Visible Language 32:56-74.

Beesley, Kenneth (1998). Romanization, transcription and transliteration. Online: http://www.xrce. xerox.com/ Research-Development/ Historical-projects/Linguistic-Demos/Arabic-MorphologicalAnalysis-and-Generation/Romanization-Transcription-and-Transliteration; accessed March 12, 2010.

Brown, Becky (1993). The social consequences of writing Louisiana French. Language in Society 22:67-101.

Brown, Reverend George (1854). The history of the British and foreign Bible society from its institution in 1804 to the close of its jubilee in 1854. London: Bagster and Sons, Paternoster Row.

Dale, Ian R. H. (1980). Digraphia. International Journal of the Sociology of Language 26:5-13.

Dalmia, Vasudha (1997). The nationalization of Hindu traditions: Bharatendu Hariśhchandra and nineteenth-century Banaras. Delhi: Oxford University Press.

Dalvi, Abdussattar (1971). Ibtedayiya. In Abdussattar Dalvi (ed.), Urdu men lesani tahqiq, 364. Bombay: Kokil \& Company.

Faruqi, Shamsurrahman (2006). Strategy for the survival of Urdu through school education. Annual of Urdu Studies 21:120-38.

Jaffe, Alexandra, \& and Shana Walton (2000). The voices people read: Orthography and the representation of non-standard speech. Journal of Sociolinguistics 4:561-87.

Kelkar, Ashok R. (1968). Studies in Hindi-Urdu I: Introduction and word phonology. Poona: Deccan College.

Khalidi, Omer (1995). Indian Muslims since independence. New Delhi: Vikas Publishing House.

Khan, Masud Husain (1971). Urdu sautiyat ka khaka. In Abdussattar Dalvi (ed.), Urdu men lesani tahqiq, 3-29. Bombay: Kokil \& Company.

- (1997). Mazamin-e-Masud: Adabi aur lesani mazamin ka majmua. Aligarh: Educational Publishing House.

King, Christopher R. (1989). Forging a new linguistic identity: The Hindi Movement in Banars. In Sandria B. Freitag (ed.), Culture and power in Banaras: Community, performance, and environment, 1800-1890, 179-202. Berkeley: University of California Press.

- (1992). Images of virtue and vice: The Hindi-Urdu controversy in two nineteenth-century Hindi plays. In Kenneth W. Jones (ed.), Religious controversy in British India: dialogues in South Asian languages, 123-48. Albany: State University of New York.

- (1994). One language, two scripts: The Hindi movement in nineteenth century North India. Bombay: Oxford University Press.

King, Robert D. (2001). The poisonous potency of script: Hindi and Urdu. International Journal of the Sociology of Language 150:43-59.

Masud, Muhammad Khalid (ed.) (2000). Travellers in faith: Studies of the Tablighi Jamaat as a transnational Islamic movement for faith renewal. Leiden: Brill.

Mehrotra, Palash (2005). A debate between Alok Rai and Shahid Amin regarding Hindi. Annual of Urdu Studies 20:1-22.

Metcalf, Barbara (1993). Living Hadith in the Tablighi Jama'at. The Journal of Asian Studies 52:584-608.

- (2006). Urdu in India in the twenty-first century. In Ather Farouqui (ed.), Redefining Urdu politics in India, 63-71. New Delhi: Oxford University Press.

Moghni, Abdul (1998). Urdu ki zindgi aur maut ka sawal. Hamari Zaban 28:1. 
Narang, Gopichand (1974). Imlanamah: Sefarishat-e-imla Kameetee, Taraqqi Urdu Board. New Delhi: Maktaba Jamia Limited.

Orsini, Francesca (2002). The Hindi public sphere. New Delhi: Oxford University Press.

Palfreyman, David, \& Muhamed al-Khalil (2003). "A funky language for teenzz to use": Representing Gulf Arabic in instant messaging. Journal of Computer Mediated Communication 9. Online: http:// jcmc.indiana.edu/vol9/issue1/palfreyman.html; accessed March 12, 2010.

Pandey, Gyanendra (2001). Remembering partition: Violence, nationalism, and history in India. Cambridge: Cambridge University Press.

Rahman, Azizur (1923). Urdu conversational exercises. Karachi: Azizi’z Oriental Book Depot.

Rahman, Wakilur (2006). Zaban bigri to bigri thi. Rashtriya Sahara, 2. New Delhi.

Ranking, George Spiers Alexander (1895). A guide to Hindustani specially designed for the use of officers and men serving in India, including colloquial phrases in Persian and Roman character and a collection of arzis, with transliteration in Roman-Urdu and English translations. Calcutta: Thacker, Spink.

Russell, Ralph (1999). Urdu in India since independence. Economic and Political Weekly 34:44-48.

Sachar, Rajindar (2006). Social, economic and educational status of the Muslim community of India. New Delhi: Government of India.

Sahar, Abulfaiz (2001). Urdu rasm-e-khat ki tabdili ka mas'ala aur urdu duniya ka hatmi faisla. Hamari Zaban 40:1.

Schieffelin, Bambi, \& Rachelle Charlier Doucet. (1994). The "real" Haitian Creole: Ideology, metalinguistics, and orthographic choice. American Ethnologist 21:176-200.

Sebba, Mark (1998a). Phonology meets ideology: The meaning of orthographic practices in British Creole. Language Problems and Language Planning 22:19-47.

(2006). Ideology and alphabets in the former USSR. Language Problems \& Language Planning 30:99-125.

(2007). Spelling and society: The culture and politics of orthography around the world. Cambridge: Cambridge University Press.

Senrai, Anwar (2006). Urdu: Imkan, masael ummiden aur andeshe. BBC London. Online: http://www. bbc.co.uk/urdu/regional/story/2006/06/060628_urdu_london_sen.shtml; accessed February 20, 2007.

Shahabuddin, Syed (1999). Urdu and its future in India. Economic and Political Weekly 35:566.

Sharma, R. N. (1937). Roman Urdu: A comprehensive study in Hindustani. Cawnpore: R. N. Sharma.

Shirani, Mazhar M. (ed.) (1966). Maqalat-e-Hafiz Mahmud Shirani: Urdu zaban aur us ke aghaz va irtiqa se muta'aliq mazamin. Lahore: Majlis-e-Taraqqi-e-Adab.

Singh, Bhanu Pratap (2006). Urdu: Between rights and the nation. In Ather Farouqi (ed.), Redefining Urdu politics in India, 13-31. New Delhi: Oxford University Press.

Street, Brian V. (1995). Social literacies: Critical approaches to literacy in development, ethnography, and education. London: Longman.

van der Veer, Peter (1994). Religious nationalism: Hindus and Muslims in India. Berkeley: University of California Press.

Woolard, Kathryn A. (1998a). Simultaneity and bivalency as strategies in bilingualism. Journal of Linguistic Anthropology 8:3-29.

Yates, William (1836). Introduction to the Hindustani language: In three parts, viz. a grammar, vocabulary, and reading lessons. Calcutta: Baptist Mission Press.

Zavos, John (2000). The emergence of Hindu nationalism in India. New Delhi: Oxford University Press.

(Received 08 September 2009; revision received 16 July 2010; accepted 09 August 2010; final revision received) 